\title{
Halltõvega seotud tõrjevõtted ja nende liigitamine ${ }^{1}$
}

\begin{abstract}
Piret Paal
Teesid: Artiklis antakse võrdlev ülevaade halltõve ehk malaaria tekkeseletustest nii teaduslikus kui ka rahvameditsiinis ning analüüsitakse, mil moel on rahvameditsiinis omavahel seotud ravivõtted ja käsitlus haiguse päritolust. Juttudes esinevad ravimisrituaalid võivad olla nii rahvameditsiinis tuntud toimingud kui ka jutupärimusele iseloomulikud fiktsionaalsed rituaalid. Kuigi tegemist on realistlike kirjeldustega, on need võtted teatud jututüüpides kinnistunud ja neid kasutatakse eelkõige jutu huvides. Artikli keskne osa käsitleb suulise pärimuse liigitamisega seotud probleeme. Autor kasutab halltõve tõrjevõtete kirjeldamisel nn hägusaid kategooriaid, milleks on: maagilised või ratsionaalsed ravivõtted (domineerib värisevate ja tugevalõhnaliste taimede, maagilist mõju omavate loomade liha, vere ja väljaheidete kasutamine) või parandamisrituaali käigus kasutatavad pikemad või lühemad verbaalsed tõrjevormelid. Loodud kolme kategooriat ühendab uskumus, et nimetatud ravivõtted aitavad halltõve vastu sõltumata haiguse etioloogiast.
\end{abstract}

Märksõnad: arhiivitekstid, halltõbi, hägusad kategooriad, liigitamine, malaaria, muistend, rahvajutt, rahvameditsiin

Halltõvena tuntakse pärimuses haigust, mis koolimeditsiinis kannab nime malaaria. Kuuludes vanimate nakkushaiguste hulka on sellel palju erinevaid esinemisvorme. Haigus esineb korrapäraste vaheaegadega ja põhjustab äkilist temperatuuritõusu ja -langust, peavalu, väsimust, aga ka oksendamist ja deliiriumi. Malaariaviirust levitab hallasääsk (Anopheles maculipennis).

Olemasolevate andmete kohaselt on halltõveepideemiaid esinenud Eesti aladel veel 19. sajandi kolmekümnendatel aastatel. Üks laiaulatuslikumaid ja ohvriterohkemaid epideemiaid sai alguse 1827. aasta kevadel Võrumaal. Sealt levis malaaria edasi Tartumaale ning haaras 1829. aastal kogu Eesti territooriumi, saavutades maksimaalse leviku 1830. aastaks. Epideemia kõrgajal kasvas ohvite arv 5\%ni kõigist surmajuhtumitest aastas (Rootsmäe 1987: 150-151). Halltõbe käsitlevaid teateid hakati talletama 1880. aastatel. Hiliseimad vaatluse all olevad tekstid pärinevad 1960. aastatest. Veel käesoleval 
sajandil leidub inimesi, kes mäletavad halltõve olemasolu, kuid vastav jututraditsioon on suulisest pärimusest kadunud. Seepärast on halltõbe ja sellega seonduvaid käsitlusi võimalik uurida vaid arhiivitekstidele tuginedes.

Käesolev analüüs põhineb ligi 600 halltõvetekstil, mis olid e-arhiivi liidetud 2004. aasta veebruariks. Täielikult on halltõvetekstid kopeeritud Eesti Rahvaluule Arhiivi (ERA) ja Tartu Ülikooli eesti ja võrdleva rahvaluule õppetooli (EKRK) kogudest. Teiste kogude puhul kopeerimine jätkub. Suurema osa halltõvega seotud arhiivitekstidest moodustavad lühemad kirjeldused (uskumusteated), milles nimetatakse erinevaid maagilisi võtteid või loetletakse halltõve vastu kasutusel olnud sissevõetavaid ravimeid. Pikemaid ravimisriituste kirjeldusi on talletatud vähe, neid leidub näiteks memoraatides, milles jutustajad kirjeldavad isiklikke või oma lähedaste halltõvekogemusi. Arhiivi on talletatud ka pikemaid jutte halltõvest, mida iseloomustavad muinasjutuline ülesehitus, stereotüüpsed tegelased ja jutule omased tegelastevahelised opositsioonid. Ka neis usundilisi kujutelmi kajastava sisuga juttudes on läbivaks teemaks halltõvest vabanemine.

Rikkalik ravivõtetele ja tõrjemaagiale keskenduv tekstikorpus teeb halltõvest teatud mõttes erakordse haigusolendi eesti rahvausundis. Ühegi teise personifitseeritud, inimest vaevava haigusvaimu vastu pole kasutatud nii rikkalikult ravivahendeid: ravimtaimi, loomseid saadusi ja mitmesuguseid jooke. Näiteks on Eestis talletatud vaid üksikuid katkutõrjeloitse ja katkutõrje kirjeldused on sagedamini rituaalsed - näiteks katku kinni panemine või katku piiramine (Hiiemäe 1997: 70). Praktilisi ravivõtteid on märksa vähem. See võib olla tingitud katku letaalsusest, aga ka sellest, et viimased suuremad katkuepideemiad olid Eesti aladel sajand varem kui halltõveepideemiad. Luupainaja tõrjumine on samuti rituaalne, sest luupainaja põhjustena nähti eelkõige sotsiaalseid ebakõlasid. Tegemist võib olla ka traditsiooni hääbumisele omase protsessiga, milles haigusolendiga seotud usundilised kujutelmad taanduvad, kuid rahvameditsiinis olulised ravivõtted on endiselt tuntud.

Tõrjumistavade edasiandmine juttude kaudu on osa talupojaühiskonnale omasest informatsiooni jagamisest. Jutte rääkides on antud kuulajaile eelkõige selgitusi haiguse olemusest. Näiteks on halltõvejuttudesse põimitud talupere seisukohalt ohtlikud inimesed ja paigad. Nii on mainitud, et tõve toonud soldatid, meremehed või muud ringirändajad, ning hoiatatud talupere vaatepunktist ohtlike paikade eest, nagu metsaäär, veepiir ja risttee. Erinevalt mitmetest teistest eesti rahvausundis tuntud uskumusolenditest ei seostatud halltõbe mingi kindla looduses leiduva paigaga. Usundilise sisuga juttudele iseloomulikult on halltõve ilmumiskohtadeks koduring ja maagiline siirdeala koduringi ja välisilma vahel. 
Arhiivides talletatud materjal ei saa kunagi olla täiuslik ega kopeerida reaalsust, kuid see pakub võimalusi analüüsida halltõvepärimust erinevatest aspektidest. Võttes arvesse, et arhiivitekstid pole enam seotud jutustaja ja jutustamise kontekstiga, ei ole võimalik tagasi kutsuda konkreetse esitusega seotud eesmärke, tundeid ja jutustaja suhtumist esitatavasse pärimusse. Samuti pole võimalik taastada, kas jutu rääkimise eesmärk oli informatsiooni jagamine või meelelahutuse pakkumine. Kogumismeetodist lähtuv keskendumine võimalikult suure hulga tekstide talletamisele jättis tähelepanuta mitmeid olulisi küsimusi, kuid sellele vaatamata pakuvad arhiivitekstid erinevaid interpretatsioonivõimalusi.

\section{Halltõve tekkeseletused teaduslikus ja rahvameditsiinis}

Eestis levinud nakkushaigusi on oma doktoriväitekirjas Morbis inter esthonos endemicis kirjeldanud Karl Ernst von Baer (1792-1882). 19. sajandi esimesel poolel ei tuntud veel nakkushaiguste põhjusi, seetõttu käsitles K. E. von Baer endeemiliste haigustena peaaegu kõiki tänapäeval tuntud nakkushaigusi, otsides nende põhjusi eeskätt rahva ebatervetest eluviisidest, väärast toitumisest, pinnase ja õhu omadustest ning meteoroloogilistest tingimustest (Baer 1976). Rahvameditsiiniga paralleelselt arenev koolimeditsiin kopeeris paljuski rahvapäraseid ravimismeetodeid ja kasutas isegi haiguste diagnoosimisel rahvapäraseid seletusi. 18. sajandil levinud humoraalpatoloogia kirjeldas nakkushaiguste tekkepõhjustena kehamahlade paksuks ja teravaks muutumist. Arvatavalt põhjustasid haigusi külm, kuum, niiske ja roiskunud aurudega õhk, ülekuumenenud ja üleväsinud keha külmetumine, meeleliigutused, vale toitumine, vajalike toiduainete puudus, tundenärvide ärritused jne (Reinilä 1983: 137). Kuigi humoraalpatoloogia hakkas 16. sajandil taanduma, kasutasid paljud autorid analoogseid põhjendusi isegi 19. sajandil. Eriti tähtsale kohale oli haigestumise põhjuste seas paigutatud toitumine. Koolimeditsiin pidas haiguse põhjustajateks raskesti seeditavaid jahu- ja kalatoite ning muid toitumisvigu (Rootsmäe 1987: 18-19). Halltõve (nagu ka teiste nakkushaiguste) põhjusteks peeti pinnasest lähtuvat nakkuslikku auru, mis tekib orgaaniliste ainete kõdunemisel, ja haige organismis tekkinud animaalset mürki, mis kontakti teel teisele organismile edasi kandudes põhjustas haigestumise (Kalnin 1976: 60-62).

Koolimeditsiini nakkushaiguste käsitlus ei erinenud oluliselt rahvameditsiinis tuntud ratsionaalsetest seletustest. Halltõve põhjustena mainitakse 
tekstikorpuses toitumisharjumusi: vale toidu söömist (31) ja alatoitlust (3). Haiguse põhjustajatena on nimetatud veel külmetamist (9), halba õhku või tuult (7) ja ka nn närvivigu: ehmumist (5) ja viha (2). Ka on tekstikorpuses mainitud, et haiguse võisid kaasa tuua rändajad ja sõjas käinud soldatid (7). Ungarlane Mihály Hoppál nimetab haiguste enamlevinud põhjustajatena jumalaid ja vanakurjasid, kes võivad olla üleloomulikud (tundmatud) olendid või üleloomulike võimetega inimesed. M. Hoppáli järgi olid rahvameditsiinis tuntud haigustekitajateks peamiselt haigusdeemonid ja mitmesugune nõidus (Hoppál 1999). Eesti pikemate halltõvekujutelmi sisaldavate juttude kohaselt põhjustavad halltõbe inimese kujul ringi rändavad vaimolendid. Halltõvevaimude koduna kujutatakse Lapimaad, kust nad rändavad oma kehasid maha jättes Eestimaale eestlasi vaevama.

Tekstide analüüs osutab, et haigusseletus, mis sõltub sageli jutustaja eesmärkidest ja kuulajaskonna ootustest, on väga varieeruv. Mitmetasandilisus on üks rahvausundi iseloomustavamaid jooni ja traditsioonitundjal on võimalus valida mitmete sobivate seletuste vahel.

\section{Haiguskäsitlus ja ravimine}

Tõhusate ravivahendite puudumine on pannud aluse rikkalikule ravimeetodite hulgale rahvameditsiinis. Ravivõtted varieeruvad detailides, kuid on põhimõtteliselt siiski väga sarnased. Üldiselt on kasutatud teatud mõttes terapeutilisi võtteid, mille puhul peeti oluliseks etteantud skeemi veatut täitmist. Inimese vallanud võõrjõudude peletamiseks on kasutatud haige ehmatamist ja peksmist. Sageli on püütud haigust siirata võimaliku uue ohvri kallale. Maagiliste riituste osaks on olnud mitmesuguste verbaalsete vormelite kasutamine. Tõrjeriitustes võis osaleda kolm osapoolt: haige, ravija ja pealtvaatajad.

Rahvameditsiini ravimise kontseptsioon ei sisalda pelgalt parandamisvõtteid, vaid esmalt haiguse päritolu selgitamist. Käsitlus haiguse päritolust põhineb nägemusel, et haigusi põhjustavad välised tegurid. Olukorras, kus vaesus ja piiratud võimalused ohustasid kõikide ea- ja vanuserühmade esindajate tervist ning arstiteadus ei suutnud seletada haiguste põhjusi ega äkilisi surmajuhtumeid, tuli rahvameditsiinil otsida vastuseid üleloomulikest allikatest. See põhjustas meditsiini valdkonnas situatsiooni, kus usk deemonite ja nõidade pahasoovlikku käitumisse sai kõige levinumaks haigusseletuseks. Haiguste tekkimist seostati otseselt normirikkumise või mõne muu hälbega ühiskonnakorralduses (vt Honko 1993: 523-532). Haiguse põhjustajatena kujutati üliinimlike võimetega vaimolendeid, deemoneid, maa- 
giliste võimetega nõidu ja pahasoovlikke naabreid. Irdhinge kujul ringirändavad haigusvaimud pääsesid inimestesse keha loomulike avauste kaudu hetkedel, mil inimene oli kaitsetu (vt Loorits 1948). Nad võimutsesid haige üle, nõrgestades tema vastupanuvõimet. Haigusi võis põhjustada ka jumala meelepaha. Juhul, kui haiguse vastu ravi ei leitud ja haigust ei suudetud minema peletada, võis haige surra.

Halltõbe kajastavatest tekstidest selgub, et kõige sagedamini püüti haigust ravida käepäraste vahenditega ning kodustes tingimustes. Kodune haigepõetamine on olnud ennekõike naiste ülesanne. 19. sajandil moodustasid rahvameditsiinialased teadmised ühe osa taluperenaiste teadmistepagasist. Teadmine taimede ravivast toimest pärandus ühelt sugupõlvelt teisele. Lisaks ravimtaimede tundmisele kuulusid edasiantavate teadmiste hulka ka kõikvõimalikud tervendavad segud, nõidussõnad ja maagilised toimingud. Raskematel juhtudel pöörduti abi saamiseks targa poole. Külatargale oli omistatud professionaali roll ning see eristas teda muust talupoegkonnast. Tema ülesandeks oli eelkõige abivajaja nõustamine ning vajadusel ka tasakaalu taastamine.

\section{Ravivõtted või fiktiivsed rituaalid?}

Haigustele keskendunud rahvajuttude eesmärgiks on anda kuulajatele põhiteadmisi haiguste leviku ja sümptomite kohta ning juhiseid, kuidas haigust vältida ja tõrjuda. Eesti rahvajuttude uurija Reet Hiiemäe on võrrelnud kahe endeemilise nakkushaiguse, katku ja aidsiga seotud suulist pärimust ning leidnud, et sarnaselt katkupärimusele on ka aidsi levikuga seotud suulise pärimuse taustaks eelkõige inimeste teadmatus ja hirm. Juttude kaudu otsitakse võimalikke süüdlasi, esitatakse haiguste tekkepõhjusi ning hoiatatakse haiguste leviku eest (Hiiemäe 1999: 31-44). Seega võib järeldada, et haigustele keskendunud juttude puhul on tegemist teatud laadi psühholoogilise protsessiga, mille käigus osutatakse, et seletamatu päritoluga haigust on võimalik allutada käepäraste võtetega. Jutustajatele keskendunud kognitivistlikud uurimused on selgesti osutanud, et pärimuse reproduktsioon (selle esitamine ja kasutamine) on teadvustatud protsess, millel pole mingit tegemist mehhaanilise kordamisega (Kaivola-Bregenhøj 1988: 23). Kui ühele jutustajale suunatud uurimuse põhjal on võimalik välja selgitada, kui suur osa on jutustaja isiklikel arendustel, siis tekstikorpuse põhjal pole võimalik vastavaid järeldusi teha.

Psühholingvistide uurimistulemused on näidanud, et jutud esitatakse vastavalt inimese ajus olevatele skeemidele. Need skeemid on pidevas muu- 
tumises, sest iga kogemus või uus teave muudab ja korrigeerib juba olemasolevaid skeeme. Kognitivistikas on seda nimetatud hermeneutiliseks ringiks (Winograd 1981: 254-246). Ka jutustamisprotsess põhineb nendel skeemidel ja seepärast on jutu ülesehitamist võimalik iseloomustada skemaatiliselt:

1. Algus: esitatakse sündmuste toimumise aeg, koht ja tegelased.

2. Komplikatsioon: probleemi kirjeldamine, tegelastevaheline interaktsioon ja probleemi lahendamiseks vajalike toimingute sooritamine.

3. Tulemus: probleemi kõrvaldamine ja/või kontrolli alla saamine või olukorra fataalseks tunnistamine.

4. Võimalik jutustajapoolne arvamusavaldus ehk nn moraal: jutustaja kokkuvõttev kommentaar, mineviku ja oleviku võrdlus (Kaivola-Bregenhøj 1988: 35).

Ameeriklane Wayland D. Hand, kes on uurinud muinasjuttudes kasutatavaid ravivõtteid, leiab, et haigusel ja haiguse ravimisel on jutus vaid komplikatsiooni osa. See tähendab, et ravimisega seotud maagilised võtted on esitatud pealiskaudselt ega peegelda reaalsuses eksisteerinud rahvameditsiinilistele võtetele omast keerukust ja empiiriat. Rahvameditsiiniga seotud uskumused ja kasutatud ravivõtted on allutatud jutu kvaliteedi huvidele (Hand 1967: 264-265). Eesti rahvajutte ja loitse uurinud Mare Kõiva on taas osutanud, et sõnamaagia kasutamist jutupärimuses mõjutab eelkõige üldtuntus ja sobivus jutuskeemi (Kõiva 1982: 8). Kõik tekstides kirjeldatud abivahendid seisavad väga lähedal rahvameditsiinile. Seega ei ole võimalik reaalselt kasutusel olnud ravivõtteid jutule omastest fiktiivsetest tõrjemeetoditest eristada.

Ravivõtteid leidub lisaks uskumusteadetele ka pikemates muistendites. Muistendis "Halltõbi teatab oakülvi aja" on poomise teesklemisel või puu otsa ronimisel komplikatsiooni roll, mille puhul on tegemist jutule omase arendusega. Muistendis "Halltõbi kiisla naha all" suletakse halltõbi nahksesse kotti või pihlakase pulga otsa. Tegemist on realistliku kirjeldusega, kuigi on võimatu ette kujutada, et kellegi majapidamises tõepoolest oleks paar nädalat või koguni terve aasta jooksul rippunud korstnaaugus aeg-ajalt värisev haigusvaimu vangistav kott.

Catharina Raudvere on skandinaavia luupainajakujutelmi käsitlevaid arhiivitekste uurides nimetanud vastavaid toiminguid fiktiivseteks rituaalideks (fictive rituals). Ta leiab, et neid kasutatakse eeskätt jutu huvides ning reaalsuses pole sellist tegevust kunagi eksisteerinud. C. Raudvere leiab, et nende muistendite juured on sügaval igapäevaelus ja kõik fiktiivsetes rituaalides kasutatavad vahendid ja võtted omavad talupojaühiskonnas olulist rolli (Raudvere 1993: 306307). 


\section{Suulise pärimuse klassifitseerimine}

Ühe tuntuima rahvapäraste haigusseletuste liigituse on esitanud soome folklorist Lauri Honko oma teoses Krankheitsprojektile (1959). Tema põhimõtted lähtuvad sotsio-psühholoogilisest uurimissuunast ning põhinevad funktsioonianalüütilisel meetodil, milles tähtsaimaks peetakse arusaama, et üleloomulik on integreeritud igapäevaellu (Velure 1976: 42-44). L. Honko klassifikatsiooni järgi jagunevad rahvapärimuses haigusseletused viide põhirühma: tabu rikkumine, hinge kaotamine, võõra hinge sissetung, projektiil ja haiguseuss (Honko 1959: 23-34). Iseseisvate haigusvaimude poolt põhjustatud haigused on tema klassifikatsioonist välja jäänud. Nn haigusdeemoneid kõrvale jättes toetub ta mütoloogilisi haiguskujutelmi uurinud Ilmari Mannineni arvamusele, et Soomes esinevad kujutelmad haigusdeemonite põhjustatud haigustest on hilised laenud (Manninen 1922: 150). Vastava soome (peamiselt Ida-Soome ehk siis Soome-Karjala) allikmaterjali analüüs on osutanud, et ka soomlased on halltõbe (horkka, vilutauti) seostanud erilise haigusvaimu tegevusega. Lõuna-Eestis on halltõbe nimetatud näiteks veel hall, hallitõbi ja halli(h)aigus, ka eufemistlikult Lapimaa haigus. Kesk- ja Põhja-Eestis (arvatavalt ka Lääne-Eestis) on vastav nimetus külmtõbi, mis esineb ka varasemas kirjanduses. Ida-Eestis kasutatakse nimetust ork:orga (vrd Soome horkka, Vadja ja Ingeri orkka). Saaremaal tuntakse halltõbe vilu(h)aiguse (vrd Soome vilutauti) ja Hiiumaal külma(h)aiguse nime all. Ka osutab arhiivi talletatud suur ravivõtete hulk, et tegemist on vanapärase haigusega, mida on varasemal ajal hästi tuntud (Paal 2004: 107).

Soome šamaanitraditsiooni uurija Anna-Leena Siikala on haiguskäsitlusi analüüsides tõdenud, et uurijate klassifikatsioonid erinevad pärimusekandjate klassifikatsioonidest (Siikala 1978: 292). Näiteks soome rahvaarsti ehk tietäjä Minna Huovineni liigituse kohaselt jagunevad haigused (ta eristab neid tavalistest vigastustest) tekkepõhjuste järgi: 1) haigusprojektiilideks, 2) pahasoovliku inimese põhjustatuteks, 3) inimesse tunginud haiguseks ehk haigusdeemoniks ja 4) nakkushaigusteks (Siikala 1992: 77). Arstide ja ravitsejate haiguskäsitlusi võrrelnud Antti Hernesniemi kirjutab:

Ravitseja haiguskäsitlused põhinevad tema ametirühma ja teiselt poolt ka tema lähedaste, perekonna, tuttavate jne tõekspidamistel. Ravitsejatel on nii teoreetiline kui kliiniline haigusseletus. Teoreetiline seletus on pädev haiguse kohta üldiselt. Kliiniline selgitus antakse iga haige kohta eraldi (Hernesniemi 1991: 16).

Samamoodi nagu uurijate klassifikatsioonid erinevad ravitsejate omast, erinevad omavahel ka tavainimeste haiguskäsitlused. Skandinaavia ja eriti taani 
rahvameditsiini uurinud Birgitte Rørby kirjeldab, kuidas inimeste haiguskäsitlused on pidevas muutumises:

Igaüks meist teab, mida tähendab halb enesetunne: niisuguses olukorras kujundame kõik arvamusi ja tõdemusi, vaatleme ja omandame tõekspidamisi, mis on seotud haiguskogemusega. Kõikidel inimestel on olemas teadmistepagas, mis on seotud haiguste, tervise ja paranemisega. See teadmiste hulk võib isiklike või välispidiste mõjutuste abil muutuda. Märkimisväärne hulk neist teadmistest põhineb traditsiooniprotsessil, aga ülejäänud aspektid on individuaalsed (Rørbye 1982: 53).

L. Honko väidab, et haigusseletused on rahvapärimus ja rahvapärimus on elav organism, milles aina luuakse uusi formuleeringuid, seoseid ja nüansse - tõsi küll, teatud piirides. Vaatamata rahvapärimuse nüansirohkusele ja pidevale muutumisele, peab ta klassifitseerimist võimalikuks. Tema nägemuse kohaselt on uurija ülesandeks elimineerida tekstist need võtted, millest on vaid ühekordsed teated või mis liigitusse ei sobi (Honko 1958: 30). Arhiivitekstide iseloomu ja varasema folkloorikogumise eesmärke arvesse võttes näib tänapäeval mingite tekstide kõrvalejätmine mõttetu. Eriti kui arvesta$\mathrm{da}$, et tekstikorpuses leiduvad tekstid on kogutud ajal, mil ühiskonnas toimusid muutused modernse ühiskonnakorralduse suunas ja koolimeditsiin oli varasema ajaga võrreldes rahvameditsiinist kaalukama rolli omandanud (vt Grambo 1975: 106).

Kognitivistliku uurimissuuna esindajad peavad oma peaeesmärgiks kultuurisisese loogika leidmist, kultuurile omaste liigituskategooriate ja jaotuspõhimõtete väljaselgitamist. Kui varasemad uurimused püüdsid sama teha arhiivitekstide põhjal, siis kognitivistid on püüdnud tulemusi saavutada eelkõige kultuurikandjaid uurides. Folklorist Tuulikki Kurki on uurinud soome rahvameditsiini mudeleid. Ta leiab, et kognitivistide saavutatud tulemused on samamoodi ligikaudsed ja puudulikud. Isegi kõige parema tulemuse juures on uurimuse resultaadiks saadud vaid "rahvaomased" struktuurid, uurijate poolt konstrueeritud ideaalid, mis kajastavad ainult osaliselt neid struktuure, mis uuritavatel olemas on (Kurki 1996: 24).

Nii ongi halltõve ravimist kirjeldavate tekstide põhjal võimalik luua vaid hägusaid (fuzzy) kategooriaid, mis kohanduvad kogemustel põhinevate ilmingute, üleloomulike kogemuste ja sümboolsete tähenduste kirjeldamiseks. Ebatäpsuse ja hajusate piiride tõttu peetakse hägusaid kategooriaid sobivaiks eelkõige inimese mõtlemise kirjeldamisel. Mida intuitiivsem ja kujutlusel põhinevam on teadmine, seda "hägusamad" ja libisevamate piiridega on kategooriad (Kosko 1993: 34-36). Eelkõige kajastavad need tekstikorpusel põhi- 
nevat uurijapoolset nägemust parandamisvõtete lähtekohtadest. Loodud kategooriaid ühendab uskumus, et nimetatud ravivõtetest on abi halltõve vastu, sõltumata sellest, millega haiguse tekkimist seletati.

\section{Ravivõtete kolm kategooriat}

Halltõve ravimisele on iseloomulik, et haiguse perioodilisest esinemisest lähtuvalt püütakse haiget haigusest vabastada tõvehoo ajal. Teise sobiliku ravimise ajana on nimetatud neljapäeva õhtut, mis on rahvameditsiinis ja -usundis üldtuntud maagiliste riituste sooritamise aeg. Nii, nagu rahvameditsiinis üldisemalt, on ka halltõve ravis tähtsal kohal arvumaagia. Kui kolm tähistab tavaliselt ravivõtete sooritamise kordi, siis sissevõetavate rohtude puhul on oluliseks arvuks üheksa. Ussi, karunaha või vana viisutükiga peksmised, mida sooritati halltõve minemapeletamiseks, kuuluvad väga vanapäraste ravimeetodite hulka nagu paljud alljärgnevalt esitatavad toimingudki. Halltõve ravimisel on kasutatud peamiselt analoogia- ja kontaktmaagiat. See lähtub lihtsast põhimõttest, mille kohaselt ehmatusest tulnud haigust ravitakse ehmatamisega.

Ratsionaalseid ravivõtteid kasutatakse koos maagiliste toimingutega. Sissevõetavate ravimite puhul järgitakse kindlaid rituaale. Eriti oluline oli rohu nime haige eest salajas pidamine, sest usuti, et nii püsib rohi ka haiget vaevava haigusvaimu eest salajas. Ravimeid valmistati eelkõige maagilist väge omavate loomade verest, lihast, väljaheidetest ja nahast. Ravimtaimedest olid eelistatud tugevalõhnalised või värisevad taimed. Nagu ka muude kurjade jõudude peletamisel, olid abiks palja tagumiku näitamine või haiguse üle naermine (Eisen 1927: 38). Mitmed ravivõtetest olid väidetavalt nii ohtlikud, et haige seeläbi endale uue haiguse sai või isegi suri:

\section{Inimesed kõrvetasid end ahjus, uppusid vette või kaotasid oma tervise} erinevate kunsttükkidega (Hurt 1863: 21).

Selleks, et halltõve parandamisvõtetega seonduvat heterogeenset tekstihulka paremini edasi anda, olen loonud liigituse, mis jagab halltõve ravivõtted kolme rühma.

Esimese kategooria moodustavad maagilised toimingud, millest paljud esindavad eelnimetatud fiktiivseid rituaale. Sellel kategoorial on kolm alamkategooriat, mis põhinevad kujutelmadel, et:

1) halltõvevaimu eest võis ennast peita;

2) halltõbe sai inimesest välja ehmatada;

3) halltõbi ei puutunud looma ega surnut. 
Nende ravivõtete lähtekohaks on kujutelm, mille kohaselt haigusvaimu aistingud erinesid mingil moel inimese omadest ning haigusvaim võis tungida vaid elavasse inimesse.

Teise kategooriasse kuuluvad sissevõetavad ravimid, milles prevaleerivad tugevalõhnalised või värisevad taimed, ning maagilist mõju omavate loomade liha, veri, nahk ja väljaheited.

Kolmas kategooria hõlmab verbaalseid tõrjevormeleid, mida sageli kasutati paralleelselt teiste, eriti mehaaniliste ravivõtetega.

\section{Maagilised toimingud koduringis ja siirdepaikades}

Mõte sellest, et maailm koosneb kontrollitud paikadest, mida ümbritsevad ähvardavad ja ohtlikud alad, on tuttav paljudele rahvastele. Nende ohtudega seisti silmitsi siirdealadel, marginaalsetes paikades ja loomulikult kodupiirist väljaspool olles. Tegemist on nn sotsiaalse geograafia peegeldusega, milles talu ja haritav maa vastandusid metsale (Eilola 2004: 141). Ivar Paulsoni näitel moodustavad kodupiiri laiemas mõttes kultuurmaad ehk inimeste haritud põllud. Kitsamas mõttes piirdub talupoja koduring aga taluga, taluoue ja sellel asuvate hoonetega (Paulson 1997: 103). Et talupere liikmeid ähvardasid uskumuse kohaselt ohud vaid kodupiirist väljaspool olles, oli koju tagasipöördumine tasakaalu taastamiseks eriti oluline. Teateid, mille kohaselt Venemaale väljarändajad või Türgi, Krimmi, Poola ja Kaukaasia sõjas olnud sõdurid kodus taas terveks saavad, leidub tekstikorpuses kümme.

Koduring sümboliseerib turvalisust ja seepärast sooritatakse ravimist peamiselt kodus. Koduste tõrjepaikadena on nimetatud ahju (25), lauta (23), heinaküüni (15), sauna (10), riidekirstu (7) ja kartulikoobast (3). Ühe teate kohaselt leiduvat ka üks lesknaise säng, milles halltõbi maha jäävat. Piirialadel paiknevatest ravipaikadest on tuntud rukki-, kanepi- või linapõllule (4) või ubadesse peitmine, vee peale ehk järvele viimine (9), aga ka ahjuluua, -roobi või leivalabida seljas ristteele ratsutamine (13). Neid paiku võidi kasutada lihtsalt peidupaigana, on aga ka mainitud nendes kohtades sooritatud erinevaid tõrjeriitusi.

Saun on üldtuntud igasuguste haiguste ravipaigana. Halltõve ravimise otstarbel kasutati sauna kütmisel vanu kaltsusid, viisutükke ja raipeluid (3), kadakaid või õunapuid. Ühe teate kohaselt tuli seejuures kõik sauna avaused sulgeda. Teine maagilisteks riitusteks sobiv paik talumajapidamises oli ahi. Siin on taustaks vana uskumus tule puhastavast jõust. Jakob Hurda andmetel pidi haige sellisesse ahju minema, kust just leivad välja võetud olid (Hurt 1863: 21). Hallihaigele pandi veel pahupidi kasukad selga ja tehti ahjusuule tuli. Seda nimetati halltõve kõrvetamiseks. Ka on kasutatud tulega ehma- 
tamist: laps tõmmatakse läbi põleva tule, haige näol süüdatakse põlema kuivatatud hundisõnnik, haigele tehakse vanadest viisutükkidest, üheksa lehtpuu lehtedest või kadakatest tuli ümber. Sellise ravimisega liitus ka maagilisi vormeleid. Haigeid on peidetud ka riidekirstudesse, sealjuures on oluline osa usundilisel kujutelmal, et halltõbi tuleb oma ohvrit otsima ja siis ei tohi tema hüüdmisele vastata, sest muidu väristab haigus hullemini kui enne. Sama kehtis ka peidupaigana tuntud kartulikoopa kohta. Heinaküünis sooritati vaid rituaalset poomist.

Eesti rahvausundi maagilistes moondumistes on oluline koht sealaudal ja eriti seapõhul, nagu on seoses libahundipärimusega välja toonud Merili Metsvahi (Metsvahi 1998: 41). Halltõve eest leidvat varju sealaudast (4) või lammaste seast (4). Laudas maetakse hallihaige sõnniku alla (15), aetakse lambad üle või saadetakse sigade sekka magama. Sigade seas või sigade kombel magamise motiiv on tuntud ka katkupärimuses. Arvati nimelt, et katkuvaim jätab sea kombel põhus magajad rahule (Hiiemäe 1997: 68). Levinud peidupaigaks oli ka verine vastnülitud loomanahk (5), mille alla haige haigushoo ajal puges. Maagilise mõtlemise kohaselt ei puutunud halltõvevaim loomadesse ja seepärast otsiti abi ka lehmalõas seismisest (haige kaela riputati verine sea kärss), hobuse rakmete pealepanemisest (2) ning kõige lõpuks halli (3) või valge hobusega ratsutamisest. Selle taustaks on analoogiline nägemus, et kui halltõbi ratsutab haige seljas, siis pääseb haige haigusest hobusel ratsutades. Hobuse seljas tuli ratsutada tagurpidi, mille tulemusel tekitati ruuminihe.

Ruuminihet on halltõve arstimisel kasutatud muulgi viisil. Rituaalse aiaaugust läbipugemise näol on tegemist universaalse ravi- ja muundumisvõttega, mis on osaliselt kasutusel veel tänapäevalgi (Hand 1968: 379). Hallihaige võis läbi pugeda lõhkiaetud pihlakast, aiapostide või puujuurte alt (8). Kolme aiaposti alt läbipugemisest palaviku korral on 1827. aastal ülestähendusi teinud Saaremaa pastor Johann Wilhelm Ludwig von Luce (Mansikka 1945: 4). Haigele on soovitatud magamispaiga muutmist (3). Halltõbi ei leia haiget, kes on keeranud jälgi (10) ehk pannud kingad jalga, kand eespool.

Ravimise ja maagiliste riituste sooritamise paikadena on tuntud ka koduringist väljaspool asuvad siirdepaigad. Hiiumaal on veekogu ületamisel kantud taskus väikest veepudelit, et halltõbe ennetada. Sealtsamast kogutud paari teate järgi on halltõbi "nakanud" üle vee sõites, silda ületades või lahtise veel peale vaadates. Veepiir on siirdepaik ja seda on kujutatud ka nakkusvaimude eest kaitset pakkuvana. Nõnda sõuti haige haigushoo pealetuleku eel järvele või järve keskele suurele kivile (9), kusjuures haige riided jäeti kaldale (3). Abistavaks toiminguks peeti tagurpidi järve (4) (või mõnda teise veekogusse, näiteks kaevu) minekut. Kaevu on üle vasaku õla visatud 
kolm väikest kivi. Haige kõrvad peavad seejuures olema suletud, et kivi kukkumist poleks kuulda (2). Kolmel korral on haige otsinud peidupaika silla alt. Külma vett on kasutatud haige ehmatamiseks (4). Veele langevat inimese varju (5) pidas halltõbi uskumuse kohaselt surnud ohvriks ja lõpetas vaevamise.

Halltõve ennetamiseks on viidud ristteele mune. Risttee, nagu ka veepiir, on siirdepaik, mida kujutati koduringi ja muu maailma piirina. Kuna haigus pärines koduringist väljastpoolt, püüti ta kaitsvaid toiminguid appi võttes ka väljapoole tagasi viia. Mõnikord soovitati hallipõdejal jätta riided ristteele ja alasti koju joosta. Maagilist kaitset otsides ratsutati (varastatud) ahjuluua seljas ristteele, visati luud maha ja mindi tagasi vaatamata koju. Samuti on haige põgenenud rukki-, kanepi- või linapõllule, aga leidub ka teade oapeenarde vahele peitmisest.

Halltõbe on püütud siirata ka kivisse või puusse, vastavalt kolm või üheksa korda ümber objekti käies. Selline üheksa või kolm korda ringi käimine on laiemalt seotud igasuguse ohu peletamisega (Lönnrot 1984: 191). Puusse tulistamise puhul pole selge, kas on tegemist haiguse puusse siirdamise või puu otsas oleva haigusvaimu kujuteldava tapmisega.

Sarnaselt veepiiri või ristteega võis haige jätta riided ka puu otsa ja ise koju põgeneda ning siis arvati, et haigus vaevab seal haige asemel riideid. Sümboolne haiguse puusse siirdamine on levinud ravivõte astma, hambavalu, ninaverejooksu, epilepsia ja mitmete teiste haiguste puhul (Hand 1965: 66 jj). Mõnikord seoti hallitõbine ka puu külge kinni (3). Halltõvetekstides esinevat ohvri puu otsa ronimist (7) võiks pidada haiguse puusse siirdamiseks, kuigi vastava muistenditüübi järgi on haige eesmärgiks enesetapu teesklemine. Omalaadses vaheagendi funktsioonis (intermediate agent) esinevateks puudeks on eesti halltõvepärimuses haab, lepp, pihlakas, kadakas, kask ja õunapuu.

Ravimisrituaalide läbiviimise paikadena nimetatud kohad peegeldavad ravijate erinevaid taotlusi. Eesmärkideks võivad olla varjulise paiga leidmine (kartulikoobas, laut, heinaküün, põld), võimalikult mõjus ravi (saun), anastava vaimu lahkumist soosiv siirdepaik (ahi, riidekirst, risttee, veepiir). Nendes valikutes peegelduvad eeskätt usundilised kujutelmad, mis on seotud halltõvega. Laiemas mõttes aga annavad vastavad jutud edasi eestlastele omast usundilist maailmavaadet, mille järgi teatud kohtadele omistatakse välispidiste jõudude eest kaitsev või neid tõrjuv maagiline funktsioon. 


\section{Taimed ja maagilist mõju omavad segud}

Ravimtaimede kasutamine halltõve ravitsemisel on olnud üsna levinud. Esmaselt on kasutatud selliseid ravimtaimi, millest arvati abi saavat külmetuse korral, sest haige kannatas sagedasti külmavärinate käes. Esimese rühma moodustavad taimed, mida kasutati "sarnane sarnasele" ehk analoogia põhimõttest lähtudes. Kõige tuntum ravimtaim oli külmavärilill ehk värihein (Briza media):

Külmatõve lilled kasvavad metsas, nagu heina kõrs, lutika moodi marjad külles, ise värisevad. Külmtõbi tuleb raskest külmetamisest, see teeb siis terveks (ERA II 13, 182/3 (2) < Simuna khk, Avanduse vndk Richard Viidalepp < Juula Kümnik, 75 a (1928)).

Väriheintest keedeti hallihaigele teed. Kuumade jookide abil loodeti haige higistama panna, et sedaviisi haigust välja ajada. Väriheinu ei lubatud kiskuda, sest arvati, et nii võib ka kiskuja iseenesele värisemise külge saada. On teateid, et väriheina kasutati sünnitusvalude vaigistajana ning see oli hea ka väsimuse vastu. Samamoodi värisevad ka raudnõgese (Urtica Urens L.) õied. Halltõve vastu soovitati järgmist:

Si on hallitõbi, no siuke, ku inimesel siuke külm palavik on, siis raudnõgese marju (peale õitsmist küljes) võetse ja sedä antasse sisse, sü̈̈asse kuivalt neid (ERA II 123, 132 (128) < Viljandi khk, Tännassilma v < Kolga-Jaani khk, Võisiku v - Linda Köögardal < Vindi Anne, 84 a (1936)).

Veel kasutati raudnõgest (eriti raudnõgese mahla) roosi parandamiseks.

Oma sülditaolise ja väriseva väljanägemise tõttu on üheks väga populaarseks halltõve ravimiks ka "pilvetükid" (Tremella Nostoc L.) ehk erilised limaseened. Usuti, et need on taevase päritoluga (Jürgenson 1997: 60-63). Samas oli aga levinud ka arvamus, et pilvetükkidest võib saada halbu haigusi (vrd väriheinaga), loomad pidid koguni hulluks minema. Pilvetükke kasutati rabanduse, langetõve, paistetuse korral. Halltõve ravimisest pilvetükkidega räägib järgmine näide:

Jutustaja on ise näind, kui pilvetükid taevast alla langevad, siis on nagu sült, mis maa pääl ei sula. Külmatõve haiguse puhul on antudki sisse pilvetükke. Ravanduse puhul vist kah. Leitud pilvetükid korjatud purgi sisse ja hoitud alal (ERA II 13, 76 (71) < Simuna khk, Mõisama k

- Richard Viidalepp < Jüri Prinkmann, 79 a (1929)). 
Veel on halltõve ravimisel kasutatud sooaukudes kasvavat ubalehte (Menyanthes trifoliata L.) ja ühel juhul "päikseta kasvavat rohtu", näiteks kartuleid.

Teise rühma moodustavad tugevalõhnalised taimed. Tugevasti lõhnavate taimede kasutamine põhineb uskumusel, mille kohaselt taimede tugev lõhn takistas halltõvel ohvri leidmist. Piparmünti (Mentha piperita L.) tuntakse seedimist soodustava taimena, mis puhastab hingeõhku ja sobib nii rahustiks kui ka reumarohuks. See ajab higistama ja aitab peavalu korral. Apteegis olid saadaval ka piparmünditilgad, mida talumajapidamistes tihti kasutati. Nimetatud on spetsiaalset droogi, mis valmis piparmündist, kaneelist ja kalmusest (Acorus calamus L.). Seda segu tuli juua üks klaas päevas. Kalmust nagu piparmüntigi tunti seedimise soodustaja ja isutõstjana. Tugeva lõhna tõttu on kalmusejuuri kasutatud ka kirbutõrjeks. Keskajal on kalmusest isegi katku vastu abi otsitud. Soovitatakse ka pihlakaõie (Sorbus aucuparia L.) teed. Maavitsad (Solanum dulcamara L.), mille värsked võsud lõhnavad uimastavalt, on tuntud peamiselt maa-aluste (Soomre 2000: 111) ja jooksva (jooksvarohi) ravimina, kuid neid kasutati ka ohatise ja umbpaistetuse raviks. Ka katkuohu korral soovitati inimestel põletada healōhnalisi aineid, et ohtlikku nakkustkandvat õhku neutraliseerida (Hiiemäe 2003). Kirikuloos on samuti kasutatud mitmesuguseid tugevalõhnalisi taimi (nt aedruuti) just seestunud ehk deemoni mõjuvõimu alla sattunud inimeste ravimisel (Valk 1994: 149).

Järgmise sissevõetavate ainete rühma moodustavad mitmesugused segud, mille valmistamisel on kasutatud erinevate loomade verd, liha, nahka ja väljaheiteid. Arhailise uskumuse kohaselt peitus just neis tervendav vägi ja elujõud (Loorits 1932: 17). Haige toitmisel erinevate ebameeldivate asjadega oli kaks seletust. Mõlemad on seotud haiguse kehast väljaajamisega. Esimene põhines arvamusel, et kui haige sööb ainult ebameeldivat ja tugevalõhnalist toitu, lahkub haigus haige kehast. Teine selgitus oli haige oksendama ajamine, et sel moel haigust välja ajada. Haigele anti siili verd või liha (3), konna verd või konnaleotise vett (5), musta ussi tuhka või ussivett (3), roti, kassi, hundi, musta lehma, musta oina või koera sõnnikut ja uriini ning muti, roti, hiire või konna liha. Väga levinud oli ka inimese uriini tarvitamine (9), mida mõnikord pidi jooma kinga kannast. Kasu arvati olevat ka sooja piima joomisest, kusjuures eraldi on välja toodud musta mära piim. Lisaks on haigele antud looma järelsünnitust (platsenta), üheksa vihmaussi tuhka, üheksa muna (3), haige juukseid koos kolme veretilgaga, üheksa täid või täisuppi (3) ning okset (3). Ka on haigele antud üheksa jõe vett ja viina (10). Üks kord on nimetatud püssirohtu, juudasitta, sütt, leitud leiba, elusat kala ja teise kala seest leitud kala, kadakavett ja türgi pipra viina. 


\section{Verbaalne haigusetõrje}

Eesti loitse on tugevasti mõjutanud kristlik traditsioon, kusjuures mõjutusi on tulnud nii idaslaavi kui Lääne-Euroopa kristlike tekstide seast (Kõiva 1995: 183-194; Kõiva 1998: 190-213). Maagilised rituaalid ja sõnade või vormelite kasutamine on käinud paralleelselt. Tuntuim maagiline tegevus, kus ka sõnu kasutati, on halltõve kõrvetamine, mis tähendas, et haige pandi ahju ja parandaja seisis ahjusuu ees valvel. Mõnikord halltõbe lihtsalt hoiatati, et kui see minema ei lähe, jäetaksegi hallipõdeja tulle. Palamuselt kirjutatakse:

Haige pugegu ahju, üks kõrvetagu ahjusuu ees kadakaid, teine küsigu ukse pealt: "Mis te seal kõrvetate?" - "Külmatõbe, külmatõbe!" (H II 27, 272 (16d) < Palamuse khk, Luua v - Helene Masen (1888)).

Analoogset dialoogil põhinevat tõrjevormelit on kasutatud ka nari (randmeliigese põletiku) ja lastehaiguste ravimisel ning kilkide ja prussakate tõrjeks (Kõiva 1981: 7).

Haigust on häbistatud pekstes haiget luuavarrega: Oo, lapumaalits, mes sä siit otsit?! (ERA II 2, 643 (3) < Karula khk, Karula v - Herbert Tampere < Lota Rästas, 74 a (1928)) või kasutatud maagilist kaitset pakkuvaid obstsöönsusi: Laku perset, sa vana lits! Ega sa mind enam kätte ei saa! (ERA II 13, 87/8 (1) < Simuna khk, Mõisama vndk < Tartumaa - Richard Viidalepp < Ann Kangur, 77 a (1928)). Peksmine hinge vallanud deemonite väljaajamiseks on eriti tuntud kristliku kiriku ajaloos. Põlvamaalt on üles tähendatud, et kurjast vaimust vaevatud inimene saab terveks, kui teda peksta kas kadjatse vitsaga või pihlitse nuijaga (Hurt 1863: 12). Vitsutamine tervise toojana ja heaolu tagajana on rahvatraditsioonis laiemalt tuntud. Levinud on palmipuudepüha-aegne urbimine (Hiiemäe 1981: 140-142). Tuntakse ka mardisante, kes vitstega pererahvast nüpeldasid, soovides: Tooreks, terveks! Ülo Valk kirjutab, et vitsutamist on kasutatud ka ristimisjärgse toiminguna, kus see märgib sama siirderituaali mis veega pesemine või vihtumine (Valk 1998: 153).

Hallitõbist peksti ussiga või ussi meenutava märja köie (3), pihlakast kepi (2), ahjuluua (2), karunaha, lepavitsa või vanade viiskudega. Tavaliselt tabas peks haiget ootamatult. Peksmise ühe eesmärgina nähti haiguse väljaehmatamist. Haigele on ka kirves selga seotud ja voodisse asetatud luupainaja tõrjes kasutusel olnud terariistu (2). Ka on haige pea pakule pandud ja ähvardatud kirvega pea maha raiuda, kui haigus ei lahku. 
Halltõve puhul on sageli kasutatud tähtvormelit abracadabra. Euroopas on abracadabrat kasutatud palaviku ja hambavalu vastu ning haavade parandamisel. Eestis oli see arstimisloitsu funktsioonis. Lisaks halltõvele kasutati sama vormelit marutaudi ja haruldase teate järgi ka nari raviks (Kõiva 1998: 198). Teade kirjutati paberile või leivale ja anti haigele tema enda teadmata sisse:

Saab võetud üks neljanurgeline tükk sinist suhkrupaberid ja allpool seisvaid tähed peale kirjutatud ja iga nelja nurga külge rohelist lõnga seutud. - Siis peab haige isi omale ümber siduma niimoodi kui üks manisk ja peab just 24 tundi pidama. Kui aeg täis ja ära võetud, peab haige ühe veikse kivi selle paberi sisse mässima ja ühe kõrvalise koha või jõe äärde minema, üle ôla selja taha viskama ja tagasi tulles mitte selja taha vaatama. Sõnad on järgmised

An-bra kula
An-brakul
Anbraku
Anbrak
Anbra
Anbr
Anb
An
$A$

(H IV 1, 354/5 (8) < Koeru khk - Richard Rapin (1889)).

"Kadugu haigus"-vormeleid on kasutatud eriti juba eelmainitud rituaalse läbipugemise juures. Ühe teate kohaselt pandi kolm ämblikku siidlapi sisse ja asetati südame kohale. Siis tehti pihlakapuu pooleks ja selle kiilu vahelt tuli kolm korda läbi minna, sealjuures kolm korda öelda: Kadugu haigus ja ärgu iialgi tagasi tulgu! (RKM II 159, 150/1 (5) < Rakvere 1 - Ervine Kasemets < Leena Osmein, s 1897 (1963)). Halltõve põdejale antud sellist leiba, mille peale on pandud ämblikuvõrku. Haige võis ka aia tugiteivaste alt läbi pugeda ja sealjuures hüüda: Mine ära, külmtõbi, külmtõbi, mine ära! (H II 27, 272 (14a) < Palamuse khk, Luua v - Helene Masen (1888)). Hobuserakmetega kinniseotud haigele loeti peale sõnad: Hall halv habõnik, kurivaim, kodolda kõblas, mine timä säläst arr! (H II 70, 254/9 (8) < Vastseliina khk - Jaan Sandra (1903)).

"Meie isa" palve, mida kasutati väga paljude erinevate haiguste puhul (nikastus, kõrvahaigused, paistetus, palavik, rabandus, kooljaluu jne), on olnud tuntud ka halltõve tohterdamisel. Palvesõnad loetakse vee peale. Mõnikord kasutatakse vett, kuhu on risti asetatud pulkade vahel lastud 
sisse hõõguvad söed. Siis antakse haigele vett juua. Parandamiskirjelduste seas on levinud ka tekstid, kus haige pidi kas ahjuluua, ahjuroobi või leivalabida seljas kolmel kolmapäeva õhtul ümber maja sõitma. Seda tegevust saatis järgmine loits:

Kolm kolmapäiwä̃odagut, neli nelä-päiwäõdagut, kirrew kiwi, kikkahari, aid-saiwas, sara-puu puhm, ahjo-luud, roobi-hand, hall page mant. (Wiedemann 1876: 400).

Üks haruldane teade halltõve ravimisest halltõve sõnadega on pärit Võnnust:

Taavita lauluraamatu 36. ptk. 7. salm on hallitõbe salm: "Jehoova mäed on kõrged..." Viimane sõna on: "Aavitab inimest, aavitab lojust." Seda peab siis ühe sulglooma pääle [kui praetud on] lugema ja issameie palve ka. Siis peab avitama (ERA II 78, 65/6 (7) < Tartu l < Võnnu khk, Ahja v - Richard Viidalepp < Juuli Suits, s 1861 (1933)).

On tuntud ka mõned lihtsamad tõrjevormelid nagu: Issand nuhtle, aga ära raputa (RKM II 381, 37/39 (23) < Rakvere khk, Vihula v, Võhma k - Helmi Rohtla (1985)) või Sa jumala vägi, sa isi näed ja oled kohtumõistja (ERA II 13, 602 (11) < Simuna khk, Mustvee al < Põltsamaa khk, Adavere v - Richard Viidalepp < Katarina Balalaikin, ligi 100 a (1928)). Setumaalt on üles kirjutatud halltõveteemaline improvisatsioon:

Hullu halli, sussi talli, lume hange, heäde kange. Mingo, kus ta päris tare. Püha Maarja, püha poiga! Saago tõbelista kaitsma (EKÜ, F 232i, 113/4 (14) < Võru l - Friedrich Reinhold Kreutzwald (1850?)).

Halltõve peletamiseks on kasutatud ka valuvastaseid loitse, milles tõbi saadeti kas kivi või puu sisse.

Eesti loitsutraditsioonile tüüpiliselt on ka halltõve puhul kasutatavad vormelid väga erineva sisu ja kujuga. Loitsu puhul pole oluline niivõrd teksti kunstiline viimistletus, kuivõrd selle eesmärk: kuidas ta aitab teha edukalt tööd, korraldada paremini elu ja suhteid või võidelda haigustega (Kõivupuu 2000: 35). Tavaliselt on üles kirjutatud vaid loitsu tekst. Harvem esineb kirjeldusi loitsu saatvatest toimingutest. Et tegemist on väga heterogeense tekstikogumiga, pole võimalik välja tuua eelistatud tõrjevormeleid, teistest sagedamini on küll kasutusel olnud abracadabra. Kuna nii haige sümboolne kõrvetamine kui ka läbipugemine ja ratsutamine on pikemates juttudes levinud, võib oletada, et nende tegevustega on ühendatud ka sõnamaagial põhinev haiguse tõrje. 


\section{Kokkuvõte}

Uurijale on liigituse loomine vajalik eeskätt heterogeense tekstikorpuse paremaks edasiandmiseks. On olnud aegu, mil liigitusse sobimatud tekstid on soovitatud kõrvale jätta. Arhiivitekstide kogumislugu arvesse võttes tundub selline ellimineerimine tänapäeval sobimatuna.

Kognitivistide püüdlused kultuurisisese loogika leidmisel on andnud tulemuseks siiski ainult uurijatepoolseid ideaale n-ö rahvaomastest struktuuridest. Seepärast on käesolevas artiklis esitatud liigituse aluseks võetud hägusa loogika teooria ja selles leiduvad libisevate piiridega kategooriad.

Halltõve tõrjevõtted on jagatud kolme kategooriasse: maagilised toimingud, sissevõetavad ravimid ja sõnamaagia. Maagiliste toimingute kategooriasse on liigitatud ka muistendites leiduvad fiktiivsed ravivõtted, mille puhul ei saa kindlalt väita, et sellised toimingud oleksid rahvameditsiinis tegelikult kasutusel olnud. Loodud kategooriaid ühendab uskumus, et tõrjevõtetest oli abi halltõve vastu. Libisevate piiridega kategooriate abil on võimalik osutada, et tegelikkuses (ravimisprotsessi käigus) on erinevatesse kategooriatesse paigutatud ravivõtteid kasutatud samaaegselt. Erinevate võtete ühendamisega püüti tagada, et haige võiks võimalikult kiiresti tagasi pöörduda oma igapäevase tegevuse juurde.

\section{Kommentaar}

1 Kirjutis põhineb autori 2004. aastal Tartu Ülikoolis kaitstud magistritööl Eesti ja Soome-Karjala halltõvepärimus. Arhiivitekstidel põhinev analüüs.

\section{Arhiiviallikad}

$\mathrm{H}=$ Jakob Hurda rahvaluulekogu, 1860-1906

ERA = Eesti Rahvaluule Arhiivi rahvaluulekogu, 1927-1944

EKÜ = Eestimaa Kirjandusliku Ühingu rahvaluulekogu, 19. saj algus - 1890

RKM = Riikliku Kirjandusmuuseumi (nüüd Eesti Kirjandusmuuseumi) rahvaluulekogu, 1945-1996. 


\section{Kirjandus}

Baer, Karl Ernst von 1976. Eestlaste endeemilistest haigustest. Loomingu Raamatukogu 33 (977). Tallinn: Perioodika.

Eilola, Jari 2004. Rajojen noituus ja taikuus. Katajala-Peltomaa, Sari \& Toivo, Raisa Maria (toim). Paholainen, noituus ja magia - kristinuskon kääntöpuoli: Pahuuden kuvasto vanhassa maailmassa. Tietolipas 203. Helsinki: Suomalaisen Kirjallisuuden Seura, lk 136-186.

Eisen, Matthias Johann 1927. Kuri silm. Eesti Kirjandus 1, lk 34-43 \& 3, lk 143-156.

Grambo, Ronald 1975. Models of Magic - some Prelimenary Considerations. Norveg: Ny serie 18, lk 77-109.

Hand, Wayland Debs 1965. The Magical Transference of Disease. Folklore Studies in Honor Arthur Palmer Hudson, North Carolina Folklore 13. Los Angeles, California: University of California, lk 83-109.

Hand, Wayland Debs 1967. Curative Practice in Folk Tales. Fabula 9, lk 264-269.

Hand, Wayland Debs 1968. "Passing Through": Folk Medical Magic and Symbolism. Proceedings of the American Philosophical Society 112: 6, lk 379-402.

Hernesniemi, Antti 1991. Lääkärin ja kansanparantajan sairauskäsitykset. Pohakka: Lehti kansanlääkinnästä 4: 1-2, Kansanlääkintäkeskus, lk 14-20.

Hiiemäe, Mall 1981 (koost). Eesti rahvakalender 2. Tallinn: Eesti Raamat.

Hiiemäe, Reet 1997. Eesti katkupärimus. Monumenta Estoniae antiquae II: Eesti muistendid: Mütoloogilised haigused 1. Tallinn: Eesti Keele Instituut.

Hiiemäe, Reet 1999. Katk ja aids - sarnaste fenomenide käsitlemine rahvapärimuses. Kalmre, Eda (toim). Kuuldust-nähtust. Tänapäeva folkloorist IV. Tartu: Eesti Kirjandusmuuseum, lk 31-44.

Hiiemäe, Reet 2003. Katkupärimuse kujunemist mõjustavatest teguritest. Mäetagused: Hüperajakiri 22, lk 80-94 (http://www.folklore.ee/tagused/nr22/reetkatk.pdf 5. november 2004).

Honko, Lauri 1958. Tautiprojektiilit: Erään varhaiskantaisen taudinselityksen tarkastelua. S-sarja / Helsingin yliopisto, folkloristiikan laitos 73. Helsinki: Kansanrunoustieteen laitos.

Honko, Lauri 1959. Krankheitsprojektile: Untersuchung über eine urtümliche Krankheitserklärung. Folklore Fellows Communications 178. Helsinki: Academia Scientiarum Fennica.

Honko, Lauri 1993. Healing. Honko, Lauri \& Timonen, Senni \& Branch, Michael. The Great Bear: A Thematic Anthology of Oral Poetry in Finno-Ugrian Languages. Suomalaisen Kirjallisuuden Seuran toimituksia 533. Helsinki: Suomalaisen Kirjallisuuden Seura, lk 523-532.

Hoppál, Mihály 1999. Sümbolravi ungari rahvameditsiinis (http://www.folklore.ee/rl/ folkte/sugri/ungari/ungari.html - 10. veebruar 2005). 
Hurt, Jakob 1863. Beiträge zur Kenntniss estnischer Sagen und Überlieferungen (Aus dem Kirchspiel Pölwe). Dorpat: E. J. Karow, Universitäts-Buchhändler.

Jürgenson, Aivar 1997. Puugipask, mahasadanud pilved ja taevased seened. Mäetagused. Hüperajakiri 4, lk 57-64 (http://www.folklore.ee/tagused/nr4/pilv.htm - 12. september 2006).

Kaivola-Bregenhøj, Annikki 1988. Kertomus ja kerronta. Suomalaisen Kirjallisuuden Seuran toimituksia 480. Helsinki: Suomalaisen kirjallisuuden seura.

Kalnin, Viktor 1976. Ääremärkusi ja selgitusi K. E. von Baeri doktoriväitekirja juurde. Baer, Karl Ernst von. Eestlaste endeemilistest haigustest. Loomingu Raamatukogu 33 (977). Tallinn: Perioodika, lk 59-62.

Kosko, Bart 1993. Sumea logiikka. Helsinki: Art House.

Kurki, Tuulikki 1996. Kansanparantamisen mallintamisesta. Kortelainen, Kaisu \& Vakimo, Sinikka (toim). Tradition edessä: Kirjoituksia perinteestä ja kulttuurista. Kultaneito 1. Helsinki: Suomen kansantietouden tutkijain seura: Tiedekirja, lk 23-37.

Kõiva, Mare 1981. Dialoogivormelid eesti loitsudes. III kevadsessioon, 23. aprill 1981: ettekannete teesid. Tartu: Eesti NSV Teaduste Akadeemia, lk 5-8.

Kõiva, Mare 1982. Sõnamaagia rahvajuttudes. IV kevadsessioon, 26.-27. aprill 1982: ettekannete teesid. Tartu: Eesti NSV Teaduste Akadeemia, 7-9.

Kõiva, Mare 1995. Loitsust riituseni. Hiiemäe, Mall \& Kõiva, Mare (toim). Rahvausund tänapäeval. Tartu: Eesti TA Eesti Keele Instituut, lk 175-194.

Kõiva, Mare 1998. Palindroomidest, aga ennekõike tähtvormelitest. Kalda, Mare \& Kõiva, Mare (toim). Sator 1: Artikleid usundi- ja kombeloost. Tartu: Eesti Keele Instituut, lk 190-213.

Kõivupuu, Marju 2000. Rahvaarstid Võrumaalt: Noor ja vana Suri Hargla kihelkonnast. Võru: Võro Instituut.

Loorits, Oskar 1932.Zur Estnischen Kulturgeschichte: Vorzeit, Sprache, Volksdichtung und Mythologie, materielle Kultur. Tartu: Akadeemiline Kooperatiiv.

Loorits, Oskar 1948 [1932]. Eesti rahvausundi maailmavaade. Stockholm: Eesti Raamat.

Lönnrot, Elias 1984 [1832]. Suomalaisten maagisista parannuskeinoista. Laaksonen Pekka (toim). Lönnrotin aika. Kalevalaseuran vuosikirja 64. Helsinki: Suomalaisen Kirjallisuuden Seura, lk 189-194.

Manninen, Ilmari 1922. Die dämonistischen Krankheiten im finnischen Volksaberglauben:Vergleichende volksmedizinische Untersuchung. Folklore Fellows Communications 45. Helsinki: Suomalainen tiedeakatemia.

Mansikka, Viljo Johannes 1945. Zur Estnischen Volksheilkunde. Mitteilungen des Vereins für finnische Volkskunde 1-2. Helsinki: Verein für Finnische Volkskunde, lk 1-14.

Metsvahi, Merili 1998. Eesti libahundipärimus: Elavast rahvausust muistenditüüpideni. Bakalaureusetöö. Käsikiri. Tartu Ülikool: Eesti ja võrdleva rahvaluule õppetool. 
Paal, Piret 2004. Eesti ja Soome-Karjala halltõvepärimus: Arhiivitekstidel põhinev analü̈̈s. Magistritöö. Tartu :Tartu Ülikool (http://www.utlib.ee/ekollekt/diss/mag/ 2004/b16954026/paal.pdf - 12. september 2006).

Paulson, Ivar 1997 [1966]. Vana eesti rahvausk: Usundiloolisi esseid. Tartu: Ilmamaa.

Raudvere, Catharina 1993. Föreställningar om maran i nordisk folktro. Studies in History of Religions 1. Lund: Lunds universitet.

Reinilä, Anna-Maria 1983. Lääkintä-ja terveyskirjallisuus maallikoiden käsissä. Laaksonen, Pekka \& Piela, Ulla (toim). Kansa parantaa. Kalevalaseuran vuosikirja 63. Helsinki: Suomalaisen Kirjallisuuden Seura, lk 130-144.

Rootsmäe, Lemming 1987. Nakkushaigused surma põhjustena Eestis 1711-1850. Tallinn: Valgus.

Rørbye, Birgitte 1982. Ethnomedicine. Ethnologia Scandinavica: A Journal for Nordic Ethnology, lk 53-85.

Siikala, Anna-Leena 1978. Miten vanha pohja on parantamisnäytelmän kaava? Laatunen, Saima-Liisa (toim). Lännen maita ja Karjalan kyliä. Kalevalaseuran vuosikirja 58. Porvoo \& Helsinki \& Juva: Söderström, lk 291-301.

Siikala, Anna-Leena 1992. Suomalainen šamanismi: Mielikuvien historiaa. Suomalaisen Kirjallisuuden Seuran toimituksia 565. Helsinki: Suomalaisen Kirjallisuuden Seura.

Soomre, Kristel 2000. Eesti maa-alustega seotud tekstide liigitamine. Hiiemäe, Mall \& Oras, Janika. Maa-alused. Pro Folkloristica 7. Tartu: Eesti Kirjandusmuuseum, lk $97-105$.

Valk, Ülo 1994. Kurat Euroopa usundiloos: Sissejuhatus demonoloogiasse. Tallinn: Vikerkaar.

Valk, Ülo 1998. Ristimise tähendusest eestlastele. Kalda, Mare \& Kõiva, Mare (toim). Sator 1: Artikleid usundi-ja kombeloost. Tartu: Eesti Keele Instituut, lk 137-156.

Velure, Magne 1976. Hovuddrag i nordisk folketruforskning 1850-1975. Velure, Magne (toim). Fataburen: Nordiska museets och Skansens årsbok. Stockholm: Nordiska museet, lk 21-48.

Wiedemann, F. J. 1876. Aus dem Inneren und Äusseren Leben der Ehsten: der Akademie vorgelegt am 30. Sept. 1875. St.-Petersburg: Keiserliche Akademie der Wissenschaften (http://haldjas.folklore.ee/rl/pubte/ee/vanad/aiale/ - 12. september 2006).

Winograd, Terry 1981. What does it mean to understand language? Norman, Donald A. (toim). Perspectives on Cognitive Science. Norwood (New Jersey): Ablex and Erlbaum Associates, lk 231-264. 


\title{
Summary \\ Practical Magic Connected with Ague (Malaria) and its Categories
}

\author{
Piret Paal
}

Key words: archive texts, ague, fuzzy categories, classification, malaria, legend, folk tale, folk medicine

This article is a part of my MA thesis entitled Estonian and Finnish-Karelian Ague Tradition - Analysed on the Basis of Archive Texts (University of Tartu, Department of Estonian and Comparative Folklore, 2004). In this article I will explore the aspects of practical magic connected with ague in Estonia and discuss the problem of classification in folk medicine research.

Ague treatment used various archaic techniques based on analogy and contact magic. I have divided these techniques into three categories, characterised by inaccuracy, flexibility, and unfixed boundaries. Many recent studies generally consider the so-called fuzzy categories the most suitable for describing human reasoning. The first group consists of magic rituals, in which the methods of treatment are based on imagery related to ague. Along with rituals, the texts also describe the use of rational methods of treatment. The herbs to be consumed for this purpose were predominantly shaky and had a pungent smell. Animal products used for this purpose include the flesh, blood, and excrements of animals that were believed to have magical powers. Verbal spells used during a healing ritual form the third category.

The healing rituals described in stories may be either common folk medicine practices or rituals characteristic of narrative tradition. Stereotypical methods of treatment include confining the disease in a tobacco pouch or taking it to a nearby farm on a horse. Although such descriptions are realistic in nature, they are fixed in certain types of narratives and used in the interest of a specific narrative. Thus, one can call them fictive rituals.

The initial function of ague legends has been sharing knowledge with a certain social group. The stories were a way of acquiring basic knowledge about the causes and the symptoms of the disease, also providing guidance on how to avoid and defeat the disease. All the records of tradition reflect ways of defeating the disease, which are typical of folk medicine practices. This psychological process of delivering relevant information by means of legend is typical of agrarian tradition, and marks the possibility of defeating a disease of unknown origin by using easily available methods. 